\title{
Intermetallic Reactions in Sn3Ag0.5Cu and Sn3Ag0.5Cu0.06Ni0.01Ge Solder BGA Packages with $\mathrm{Au} / \mathrm{Ni}$ Surface Finishes
}

\author{
T.H. CHUANG, ${ }^{1,2}$ S.F. YEN, ${ }^{1}$ and M.D. ${ }^{2 H E N G}{ }^{1}$ \\ 1.--Institute of Materials Science and Engineering, National Taiwan University, Taipei 106, \\ Taiwan. 2.-E-mail: tunghan@ntu.edu.tw
}

The intermetallic compounds (IMCs) formed during the reflow and aging of $\mathrm{Sn} 3 \mathrm{Ag} 0.5 \mathrm{Cu}$ and $\mathrm{Sn} 3 \mathrm{Ag} 0.5 \mathrm{Cu} 0.06 \mathrm{Ni} 0.01 \mathrm{Ge}$ solder BGA packages with $\mathrm{Au} / \mathrm{Ni}$ surface finishes were investigated. After reflow, the thickness of $(\mathrm{Cu}, \mathrm{Ni}$, $\mathrm{Au})_{6} \mathrm{Sn}_{5}$ interfacial IMCs in $\mathrm{Sn} 3 \mathrm{Ag} 0.5 \mathrm{Cu} 0.06 \mathrm{Ni} 0.01 \mathrm{Ge}$ was similar to that in the $\mathrm{Sn} 3 \mathrm{Ag} 0.5 \mathrm{Cu}$ specimen. The interiors of the solder balls in both packages contained $\mathrm{Ag}_{3} \mathrm{Sn}$ precipitates and brick-shaped $\mathrm{AuSn}_{4}$ IMCs. After aging at $150^{\circ} \mathrm{C}$, the growth thickness of the interfacial $(\mathrm{Ni}, \mathrm{Cu}, \mathrm{Au})_{3} \mathrm{Sn}_{4}$ intermetallic layers and the consumption of the $\mathrm{Ni}$ surface-finished layer on $\mathrm{Cu}$ the pads in Sn3Ag0.5Cu0.06Ni0.01Ge solder joints were both slightly less than those in Sn3Ag0.5Cu. In addition, a coarsening phenomenon for $\mathrm{AuSn}_{4}$ IMCs could be observed in the solder matrix of $\mathrm{Sn} 3 \mathrm{Ag} 0.5 \mathrm{Cu}$, yet this phenomenon did not occur in the case of $\mathrm{Sn} 3 \mathrm{Ag} 0.5 \mathrm{Cu} 0.06 \mathrm{Ni} 0.01 \mathrm{Ge}$. Ball shear tests revealed that the reflowed $\mathrm{Sn} 3 \mathrm{Ag} 0.5 \mathrm{Cu} 0.06 \mathrm{Ni} 0.01 \mathrm{Ge}$ packages possessed bonding strengths similar to those of the $\mathrm{Sn} 3 \mathrm{Ag} 0.5 \mathrm{Cu}$. However, aging treatment caused the ball shear strength in the Sn3Ag0.5Cu packages to degrade more than that in the Sn3Ag0.5Cu0.06Ni0.01Ge packages.

Key words: $\mathrm{Sn} 3 \mathrm{Ag} 0.5 \mathrm{Cu}, \mathrm{Sn} 3 \mathrm{Ag} 0.5 \mathrm{Cu} 0.06 \mathrm{Ni} 0.01 \mathrm{Ge}, \mathrm{Au} / \mathrm{Ni}$ surface finishes, ball-grid-array package, intermetallic compounds

\section{INTRODUCTION}

The eutectic $\mathrm{Sn}-\mathrm{Ag}-\mathrm{Cu}$ alloy system has been considered to be the most promising candidate to replace traditional $\mathrm{Sn}-37 \mathrm{~Pb}$ solders for environmental reasons. ${ }^{1} \mathrm{~A}$ Sn-Ag-Cu ternary solder has been alloyed with a trace amount of $\mathrm{Ni}$ in order to further improve its mechanical strength and wettability. ${ }^{2}$ In addition, microalloying with Ge reveals the beneficial effects of better mechanical properties and lower dross formation. ${ }^{3}$ However, Chuang and Lin have reported that the dipping of $\mathrm{Cu}$ plates into a $\mathrm{Sn}$ $3.5 \mathrm{Ag}-0.5 \mathrm{Cu}-0.07 \mathrm{Ni}-0.01 \mathrm{Ge}$ solder at $250^{\circ} \mathrm{C}$ for 15 sec results in interfacial $(\mathrm{Cu}, \mathrm{Ni})_{6} \mathrm{Sn}_{5}$ intermetallic compounds (IMCs) much thicker than are obtained by dipping into a liquid $\mathrm{Sn}-3.5 \mathrm{Ag}-0.7 \mathrm{Cu}$ solder. ${ }^{4-6}$ Through further aging of the specimens at various temperatures from 105 to $150^{\circ} \mathrm{C}$, they have found that those thicker intermetallic layers in Sn-3.5Ag-

(Received June 28, 2005; accepted October 17, 2005)
$0.5 \mathrm{Cu}-0.07 \mathrm{Ni}-0.01 \mathrm{Ge}$ solder joints possess a slower growth rate than that for undoped $\mathrm{Sn}-3.5 \mathrm{Ag}-0.5 \mathrm{Cu}$. Chuang and Lin also studied the intermetallic reactions in reflowed and aged BGA packages with $\mathrm{Sn} 3.5 \mathrm{Ag} 0.5 \mathrm{Cu}$ and $\mathrm{Sn} 3.5 \mathrm{Ag} 0.5 \mathrm{Cu} 0.07 \mathrm{Ni} 0.01 \mathrm{Ge}$ solder balls on $\mathrm{Au} / \mathrm{Ni} / \mathrm{Cu}$ pads. ${ }^{4-6}$ Three types of intermetallic phases have been observed: plate-like $\mathrm{Ag}_{3} \mathrm{Sn}$, lump-shaped $(\mathrm{Cu}, \mathrm{Ni})_{6} \mathrm{Sn}_{5}$, and thin-layer $(\mathrm{Ni}, \mathrm{Cu})_{3} \mathrm{Sn}_{4}$, and, for both solder alloys, the morphologies and total thicknesses of interfacial intermetallics are similar. In addition, aging treatments have not been shown to cause the intermetallic layers in both solder BGA packages to grow. These results were explained by Chuang and Lin: the $(\mathrm{Ni}$, $\mathrm{Cu})_{3} \mathrm{Sn}_{4}$ acts as a diffusion barrier to retard the interdiffusion of $\mathrm{Sn}$ and $\mathrm{Cu}^{6}$

In our previous study on the interfacial reactions in BGA packages with an immersion Ag surface finish, scallop-shaped $\mathrm{Cu}_{6} \mathrm{Sn}_{5}$ IMCs and a continuous $(\mathrm{Cu}, \mathrm{Ni})_{6} \mathrm{Sn}_{5}$ intermetallic layer have been observed in reflowed $\mathrm{Sn} 3 \mathrm{Ag} 0.5 \mathrm{Cu}$ and $\mathrm{Sn} 3 \mathrm{Ag} 0.5 \mathrm{Cu} 0.06 \mathrm{Ni0} .01 \mathrm{Ge}$ 


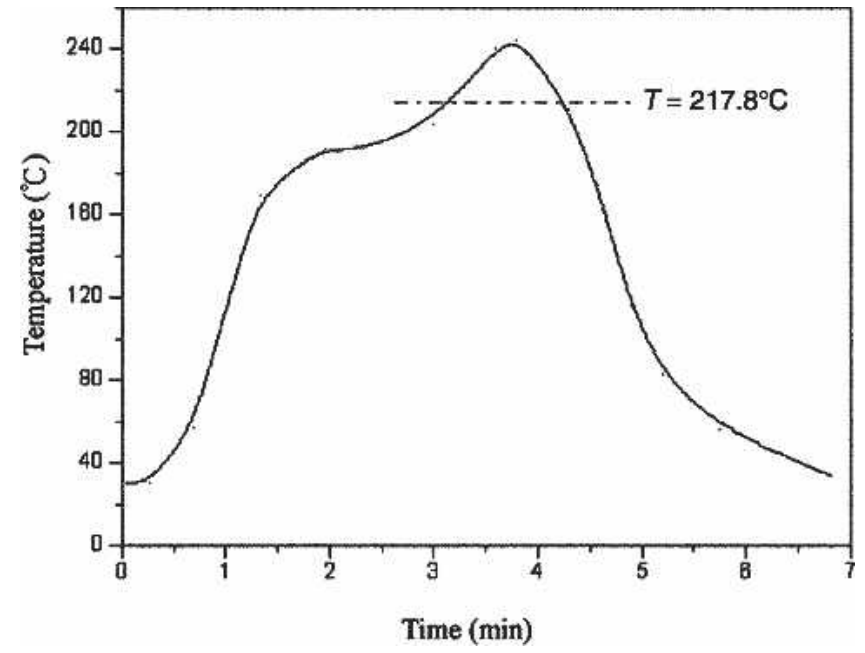

Fig. 1. Temperature profile for the reflowing process of the Sn-Ag$\mathrm{Cu}$ solder BGA packages with $\mathrm{Au} / \mathrm{Ni} / \mathrm{Cu}$ pads in this study.

solder joints, respectively. ${ }^{7}$ The interfacial intermetallics in both solder joints possess similar thicknesses. However, a thick $\mathrm{Cu}_{3} \mathrm{Sn}$ intermetallic layer with a large number of Kirkendall voids appears at the interface between the $\mathrm{Cu}_{6} \mathrm{Sn}_{5}$ intermetallic scallops and the $\mathrm{Cu}$ pads in the $\mathrm{Sn} 3 \mathrm{Ag} 0.5 \mathrm{Cu}$ specimens after aging at 125 and $150^{\circ} \mathrm{C}$. The formation of such a $\mathrm{Cu}_{3} \mathrm{Sn}$ intermetallic layer with Kirkendall voids has been effectively inhibited in the aged
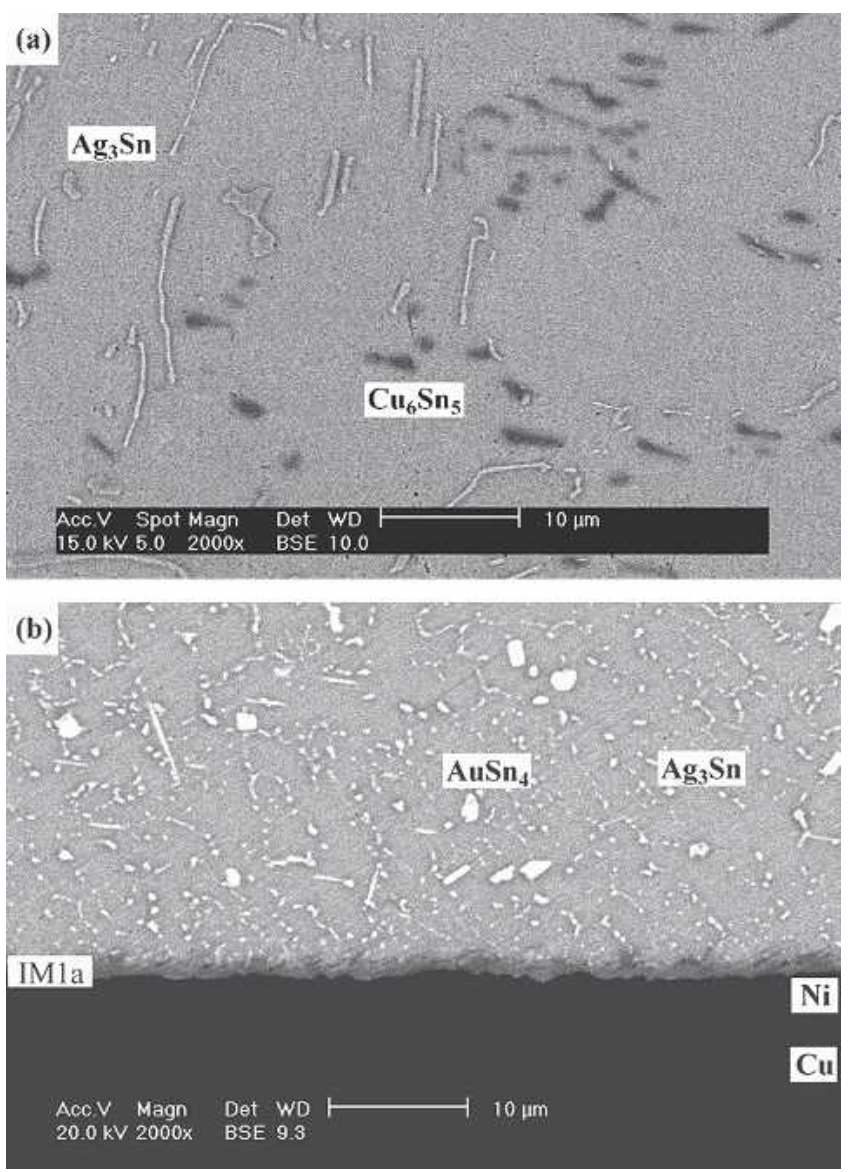

Fig. 2. Microstructure of the Sn3Ag0.5Cu solder balls before reflowing (a) and after reflowing (b) on Au/Ni/Cu pads of BGA packages.
Sn3Ag0.5Cu0.06Ni0.01Ge solder joints. In this present study, the effects of $\mathrm{Ni}$ addition on the intermetallic reactions of the reflowed and aged Sn$\mathrm{Ag}-\mathrm{Cu}$ solder BGA packages with $\mathrm{Au} / \mathrm{Ni} / \mathrm{Cu}$ pads were further investigated.

\section{EXPERIMENTAL PROCEDURES}

The geometry of the ball-grid-array (BGA) packages with $\mathrm{Au} / \mathrm{Ni}$ surface finishes used in this study was shown in a prior work. ${ }^{8}$ The Si die was attached to a bismaleimide triazine (BT) resin substrate and encapsulated with molding compound. Each package was fitted with $49 \mathrm{Cu}$ pads electroplated with $5-\mu \mathrm{m}$-thick $\mathrm{Ni}$ and immersion plated with $0.5-\mu \mathrm{m}$ thick $\mathrm{Au}$. The 0.4-mm diameter $\mathrm{Sn} 3 \mathrm{Ag} 0.5 \mathrm{Cu}$ and Sn3Ag0.5Cu0.06Ni0.01Ge (wt.\%) solder balls were dipped in rosin mildly activated (RMA) flux, placed on the $\mathrm{Au} / \mathrm{Ni} / \mathrm{Cu}$ pads, and then reflowed in a hotair furnace equipped with five heating zones. The reflow temperature profile is shown in Fig. 1, where the soaking temperature and peak temperature were set at 190 and $240^{\circ} \mathrm{C}$, respectively. Certain reflowed BGA packages were further aged at 100 and $150^{\circ} \mathrm{C}$ for various times ranging from 100 to $1000 \mathrm{hr}$.

The reflowed and aged specimens were cross sectioned through a row of solder balls, ground with
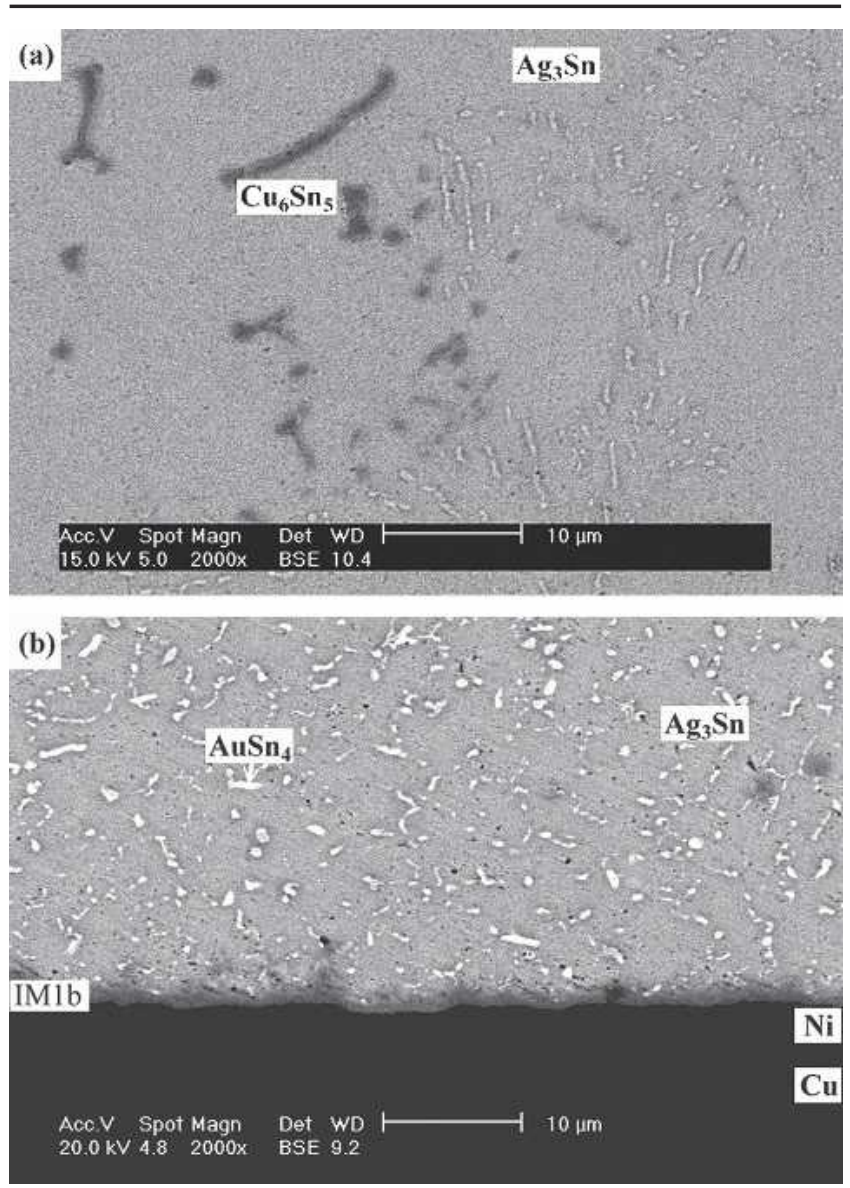

Fig. 3. Microstructure of the Sn3Ag0.5Cu0.06Ni0.01Ge solder balls before reflowing (a) and after reflowing (b) on $\mathrm{Au} / \mathrm{Ni} / \mathrm{Cu}$ pads of $\mathrm{BGA}$ packages. 
2000-grit $\mathrm{SiC}$ paper, and polished with $0.3-\mu \mathrm{m} \mathrm{Al}_{2} \mathrm{O}_{3}$ powder. The IMCs were observed via scanning electron microscopy (SEM), and their chemical compositions were analyzed using an energy-dispersive $\mathrm{x}$ ray spectrometer (EDX) installed in the SEM. For kinetic analysis, the maximum growth distances of convex scallops for each intermetallic layer were measured. The average value of a minimum of 30 measurements for each soldering condition (per reaction temperature and time) was determined to signify the intermetallic thickness $(X)$.

The bonding strengths of the solder balls on the $\mathrm{Au} / \mathrm{Ni} / \mathrm{Cu}$ pads under reflow and various aging conditions were measured via ball shear tests. For this purpose, the ball shear rate was fixed at $0.1 \mathrm{~mm} / \mathrm{sec}$ with a shear height of $80 \mu \mathrm{m}$ (about $1 / 4$ the reflowed ball height). An average value was taken from 49 measurements on each package. After the ball shear tests, the fractography of the fractured solder joints was observed with the SEM.

\section{RESULTS AND DISCUSSION}

The microstructure of Sn3Ag0.5Cu solder balls before reflow contained needle-shaped $\mathrm{Ag}_{3} \mathrm{Sn}$ and cluster-shaped $\mathrm{Cu}_{6} \mathrm{Sn}_{5}$ IMCs, as shown in Fig. 2a. Figure $2 \mathrm{~b}$ reveals that, after reflow, the needleshaped $\mathrm{Ag}_{3} \mathrm{Sn}$ precipitates resolidified into fine par- ticles, while a $\left(\mathrm{Cu}_{0.55} \mathrm{Ni}_{0.40} \mathrm{Au}_{0.05} \mathrm{Sn}_{5}\right.$ intermetallic layer (IM1a) formed at the solder/pad interface. This is evidence that the Ni surface finished layer on the $\mathrm{Cu}$ pad can attract the dissolved $\mathrm{Cu}$ atoms from the $\mathrm{Cu}_{6} \mathrm{Sn}_{5}$ clusters in the solder matrix to the solder/Ni interface. In addition, a large amount of coarse $\mathrm{AuSn}_{4}$ intermetallic bricks have appeared in the solder matrix. These $\mathrm{AuSn}_{4}$ intermetallics are derived from the rapid dissolution of the $\mathrm{Au}$ film on the $\mathrm{Ni} / \mathrm{Cu}$ pads during reflow and the ensuing reaction with the liquid $\mathrm{Sn} 3 \mathrm{Ag} 0.5 \mathrm{Cu}$ solder.

Before reflow, the $\mathrm{Sn} 3 \mathrm{Ag} 0.5 \mathrm{Cu} 0.06 \mathrm{Ni} 0.01 \mathrm{Ge}$ solder balls possessed a microstructure similar to that of $\mathrm{Sn} 3 \mathrm{Ag} 0.5 \mathrm{Cu}$, which is revealed in Fig. 3a. However, Fig. 3b shows that, after reflow, the coarse brick-shaped $\mathrm{AuSn}_{4}$ intermetallics found in the Sn3Ag0.5Cu0.06Ni0.01Ge solder matrix are of a much smaller quantity than those in the reflowed $\mathrm{Sn} 3 \mathrm{Ag} 0.5 \mathrm{Cu}$. In contrast, the $\mathrm{AuSn}_{4}$ intermetallic phase in this Ni doped $\mathrm{Sn}-\mathrm{Ag}-\mathrm{Cu}$ solder appeared as flake-shaped. The needle-shaped $\mathrm{Ag}_{3} \mathrm{Sn}$ precipitates have also resolidified into particles slightly larger in size than is the case for the reflowed $\mathrm{Sn} 3 \mathrm{Ag} 0.5 \mathrm{Cu}$ solder joints. The interfacial intermetallics in the reflowed $\mathrm{Sn} 3 \mathrm{Ag} 0.5 \mathrm{Cu} 0.06 \mathrm{Ni} 0.01 \mathrm{Ge}$ BGA package have a composition of $\left(\mathrm{Cu}_{0.64} \mathrm{Ni}_{0.34} \mathrm{Au}_{0.02}\right){ }_{6} \mathrm{Sn}_{5}$
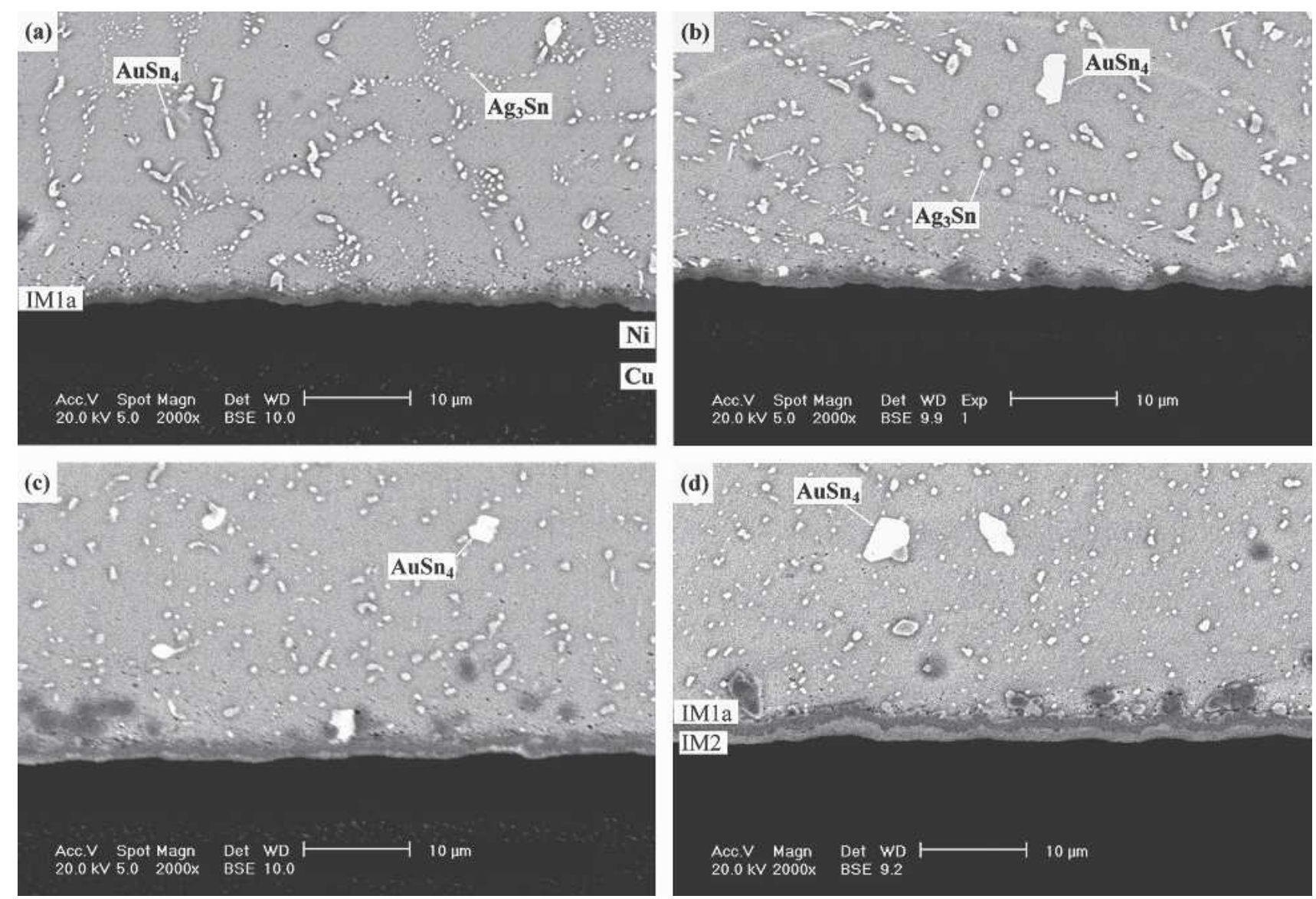

Fig. 4. Morphology of intermetallic compounds formed at the interfaces of the $\mathrm{Sn} 3 \mathrm{Ag} 0.5 \mathrm{Cu}$ solder joints on $\mathrm{Au} / \mathrm{Ni} / \mathrm{Cu}$ pads after aging at $100^{\circ} \mathrm{C}$ for various times periods: (a) $100 \mathrm{hr}$, (b) $300 \mathrm{hr}$, (c) $700 \mathrm{hr}$ and (d) $1000 \mathrm{hr}$. 
(IM1b), and their thickness is similar to that of the Sn3Ag0.5Cu specimen.

The $\mathrm{Ag}_{3} \mathrm{Sn}$ particles are seen to have coarsened from the aging of the $\mathrm{Sn} 3 \mathrm{Ag} 0.5 \mathrm{Cu}$ solder joints at $100^{\circ} \mathrm{C}$, as shown in Fig. 4. A certain number of $\mathrm{AuSn}_{4}$ intermetallic compounds in the solder matrix are also found to have grown abnormally to a relatively large size with increased aging time. However, the $\left(\mathrm{Cu}_{0.50} \mathrm{Ni}_{0.40} \mathrm{Au}_{0.05}\right)_{6} \mathrm{Sn}_{5}$ intermetallic layer (IM1a) at the solder/pad interface exhibits only slight growth. After prolonged aging for over $700 \mathrm{hr}$, an extra intermetallic layer appears between the IM1a intermetallics and $\mathrm{Ni} / \mathrm{Cu}$ pad. EDX analysis indicates that the composition of this new intermetallics layer is $\left(\mathrm{Cu}_{0.50} \mathrm{Ni}_{0.42} \mathrm{Au}_{0.08}\right)_{6} \mathrm{Sn}_{5}$ (IM2), with a $\mathrm{Au}$ content higher than IM1a After aging at $150^{\circ} \mathrm{C}$ for over $700 \mathrm{hr}$, the intermetallic layer IM2 can be seen to have grown thicker, accompanied by the appearance of many gigantic $\mathrm{AuSn}_{4}$ intermetallics in the solder matrix, as shown in Fig. 5. Furthermore, a new intermetallic layer is formed at the interface between the IM2 intermetallic layer and the Ni surface finish. EDX analysis identifies the composition (at.\%) of the newly-appeared intermetallic compound as Ni:Cu:Au:Sn = 37.16:4.98:0.54:57.32, which corresponds to the $\left(\mathrm{Ni}_{0.87} \mathrm{Cu}_{0.12} \mathrm{Au}_{0.01}\right)_{3} \mathrm{Sn}_{4}$ phase (IM3). The appearance of such a $(\mathrm{Ni}, \mathrm{Cu}$,
$\mathrm{Au})_{3} \mathrm{Sn}_{4}$ interfacial intermetallic layer (IM3) is revealed in Fig. 6 at larger magnification. In contrast, the continuous IM1a intermetallic layer has become thinner and become scallop-shaped with the increase of aging time.

For the Sn3Ag0.5Cu0.06Ni0.01Ge BGA packages, the morphology of the intermetallics in the solder matrix after aging at 100 and $150^{\circ} \mathrm{C}$ is quite different from what has been observed with the $\mathrm{Sn} 3 \mathrm{Ag} 0.5 \mathrm{Cu}$ specimens. Figures 7 and 8 show that the $\mathrm{Ag}_{3} \mathrm{Sn}$ precipitates and $\mathrm{AuSn}_{4}$ intermetallic compounds in the $\mathrm{Sn} 3 \mathrm{Ag} 0.5 \mathrm{Cu} 0.06 \mathrm{Ni} 0.01 \mathrm{Ge}$ are very slow in coarsening. Moreover, no gigantic $\mathrm{AuSn}_{4}$ intermetallics are to be found in the solder matrix of the $\mathrm{Sn} 3 \mathrm{Ag} 0.5 \mathrm{Cu} 0.06 \mathrm{Ni} 0.01 \mathrm{Ge}$, though they have appeared in the $\mathrm{Sn} 3 \mathrm{Ag} 0.5 \mathrm{Cu}$ packages (Fig. 5). The inhibition of $\mathrm{Ag}_{3} \mathrm{Sn}$ and $\mathrm{AuSn}_{4}$ coarsening for $\mathrm{Sn} 3 \mathrm{Ag} 0.5 \mathrm{Cu} 0.06 \mathrm{Ni} 0.01 \mathrm{Ge}$ might be attributed to the Ni elements in this solder alloy acting as nucleation sites, which leads to a dispersing effect of $\mathrm{Ag}_{3} \mathrm{Sn}$ precipitates and $\mathrm{AuSn}_{4}$ intermetallics. Figure 7 also shows that the thickness of the interfacial IM1b intermetallic layer remains unchanged as the aging time increases. After aging at $100^{\circ} \mathrm{C}$, there is no trace of the IM2 intermetallic layer with high $\mathrm{Au}$ content in the $\mathrm{Sn} 3 \mathrm{Ag} 0.5 \mathrm{Cu} 0.06 \mathrm{Ni0} .01 \mathrm{Ge}$, which nevertheless has been observed at the IM1a/Ni in-
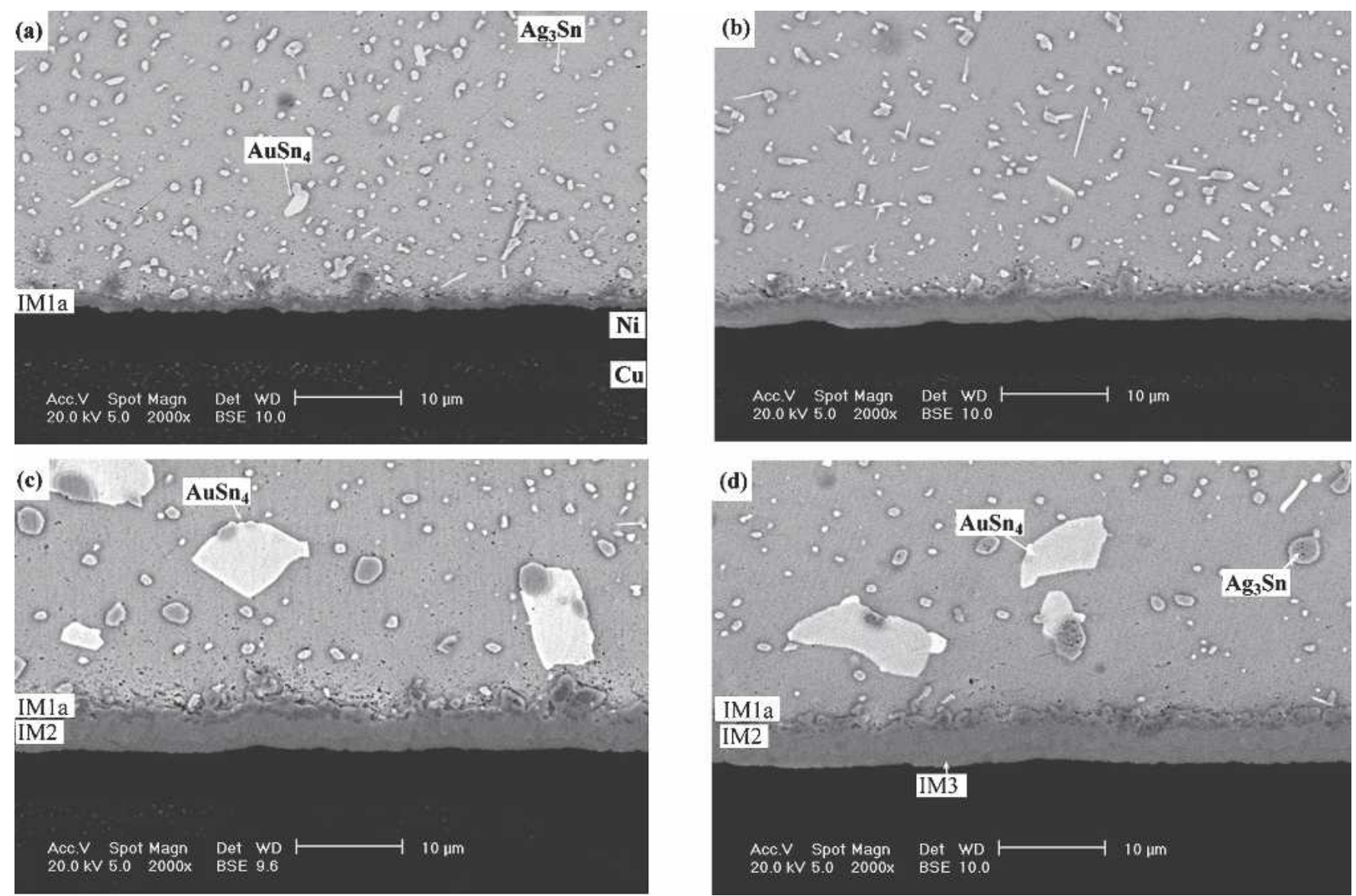

Fig. 5. Morphology of intermetallic compounds formed at the interfaces of the $\mathrm{Sn} 3 \mathrm{Ag} 0.5 \mathrm{Cu}$ solder joints on $\mathrm{Au} / \mathrm{Ni} / \mathrm{Cu}$ pads after aging at $150^{\circ} \mathrm{C}$ for various times periods: (a) $100 \mathrm{hr}$, (b) $300 \mathrm{hr}$, (c) $700 \mathrm{hr}$ and (d) $1000 \mathrm{hr}$. 

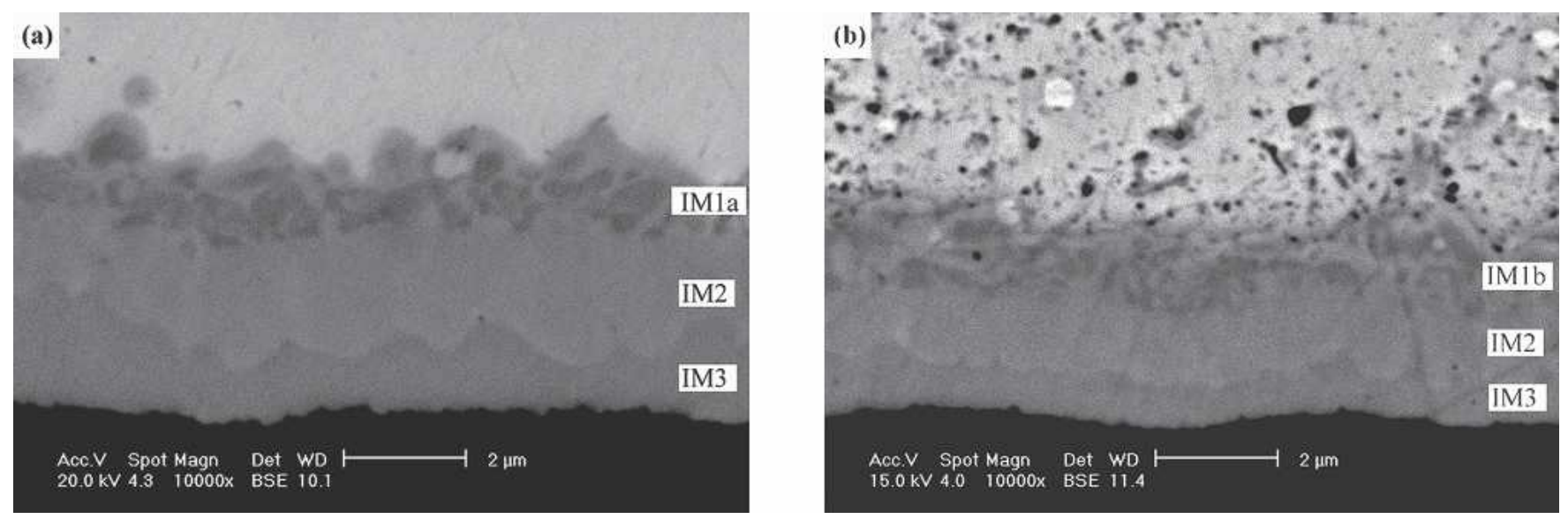

Fig. 6. Morphology of intermetallic compounds formed at the interfaces Sn3Ag0.5Cu (a) and Sn3Ag0.5Cu0.06Ni0.01Ge (b) solder joints on $\mathrm{Au} / \mathrm{Ni} / \mathrm{Cu}$ pads after aging at $150^{\circ} \mathrm{C}$ for $700 \mathrm{hr}$ with a larger magnification.

terface of the Sn3Ag0.5Cu solder joints (Fig. 4). The interfacial IM2 intermetallic layer cannot be seen in the $\mathrm{Sn} 3 \mathrm{Ag} 0.5 \mathrm{Cu} 0.06 \mathrm{Ni} 0.01 \mathrm{Ge}$ until the aging temperature is increased to $150^{\circ} \mathrm{C}$, as shown in Fig. 8 . Prolonged aging at $150^{\circ} \mathrm{C}$ for $1000 \mathrm{hr}$ can also cause the formation of a $\left(\mathrm{Ni}_{0.87} \mathrm{Cu}_{0.12} \mathrm{Au}_{0.01}\right)_{3} \mathrm{Sn}_{4}$ intermetallic layer (IM3) at the interface between the IM2 intermetallics and the Ni surface finish (see Figs. 6b and 8d). However, the growth of IM2 and IM3 inter- metallic layers in $\mathrm{Sn} 3 \mathrm{Ag} 0.5 \mathrm{Cu} 0.06 \mathrm{Ni} 0.01 \mathrm{Ge}$ solder joints is slower than that of $\mathrm{Sn} 3 \mathrm{Ag} 0.5 \mathrm{Cu}$.

For comparison, the thicknesses of interfacial intermetallic layers IM2 and IM3 in both solders after aging at 100 and $150^{\circ} \mathrm{C}$ were measured and plotted in Fig. 9a and b, respectively. Because the IM1a intermetallic layer was observed in Fig. 9c to diminish with the growing of the IM3 intermetallic layer, the residual thickness of the $\mathrm{Ni}$ surface finishes during
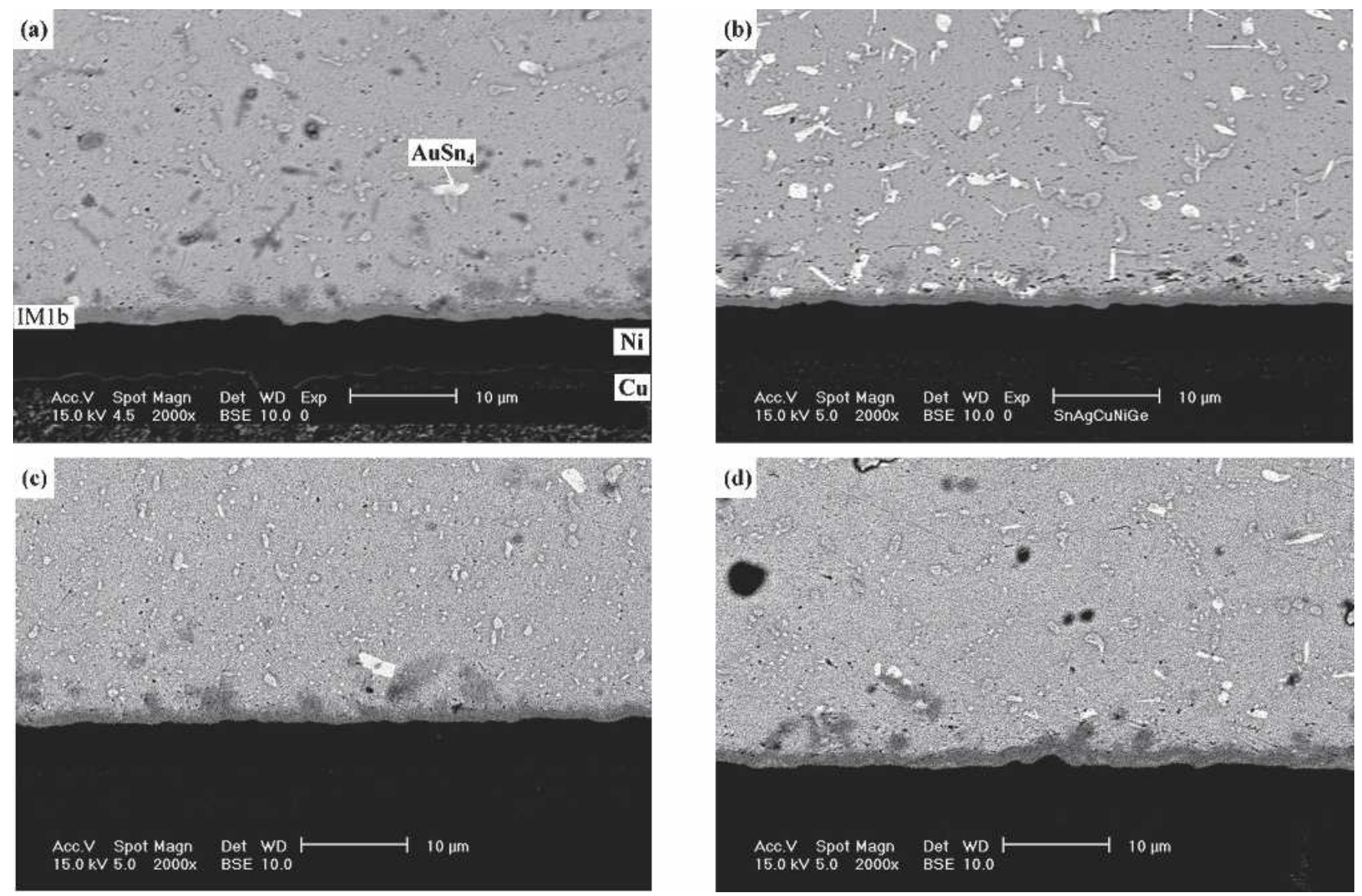

Fig. 7. Morphology of intermetallic compounds formed at the interfaces of the Sn3Ag0.5Cu0.06Ni0.01Ge solder joints on Au/Ni/Cu pads after aging at $100^{\circ} \mathrm{C}$ for various times periods: (a) $100 \mathrm{hr}$, (b) $300 \mathrm{hr}$, (c) $700 \mathrm{hr}$ and (d) $1000 \mathrm{hr}$. 

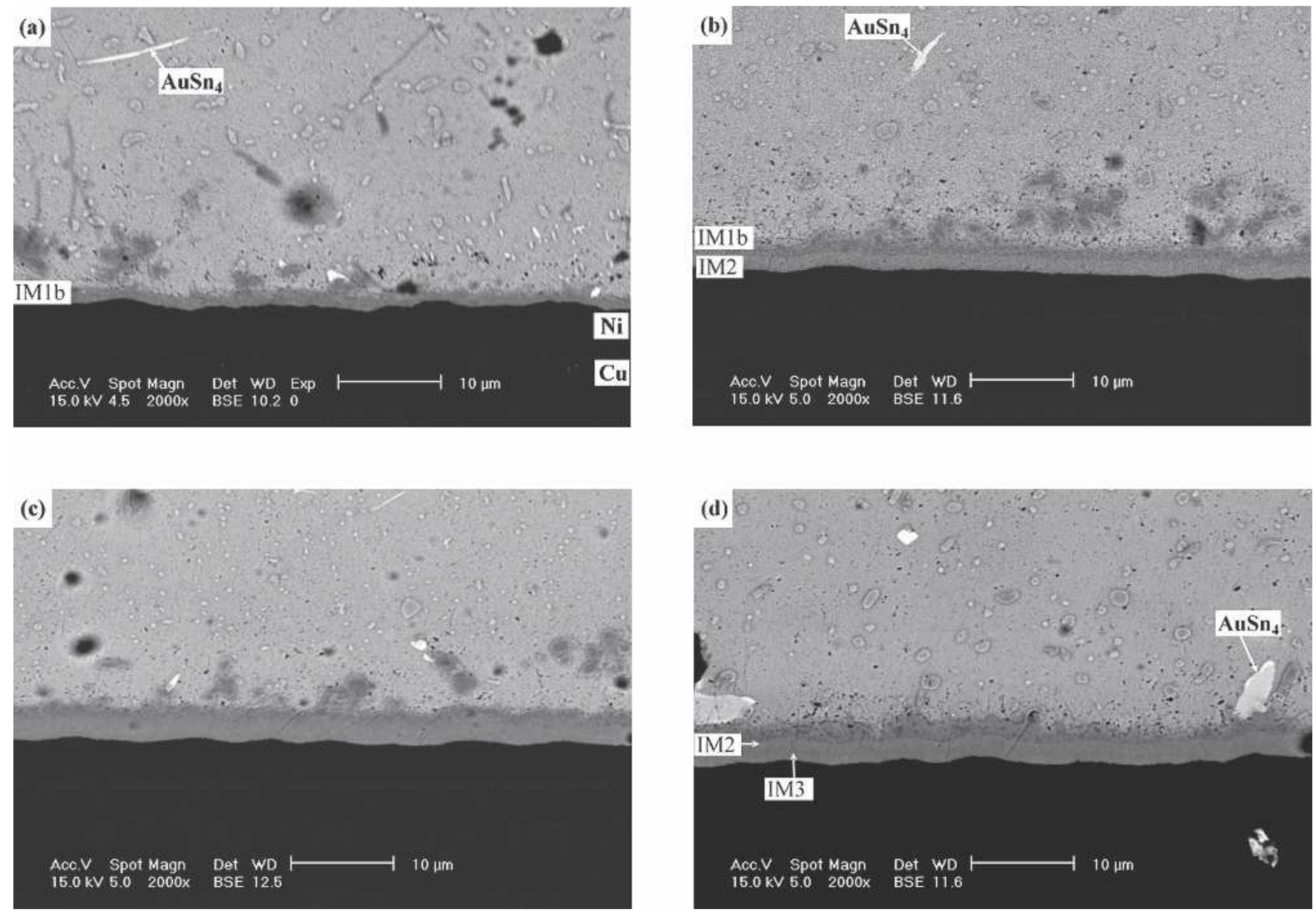

Fig. 8. Morphology of intermetallic compounds formed at the interfaces of the Sn3Ag0.5Cu0.06Ni0.01Ge solder joints on Au/Ni/Cu pads after aging at $150^{\circ} \mathrm{C}$ for various times periods: (a) $100 \mathrm{hr}$, (b) $300 \mathrm{hr}$, (c) $700 \mathrm{hr}$ and (d) $1000 \mathrm{hr}$.

the interfacial intermetallic reactions was also measured and plotted in Fig. 9d. It is evident that the growth thickness of IM2 and IM3 intermetallic layers and the consumption of the $\mathrm{Ni}$ surface finishes in $\mathrm{Sn} 3 \mathrm{Ag} 0.5 \mathrm{Cu} 0.06 \mathrm{Ni} 0.01 \mathrm{Ge}$ are both slightly less than those in the $\mathrm{Sn} 3 \mathrm{Ag} 0.5 \mathrm{Cu}$ packages.

The bonding strengths of the solder joints were measured via ball shear tests and listed in Table I and Fig. 10. The results indicate that the as-reflowed Sn $3 \mathrm{Ag} 0.5 \mathrm{Cu}$ and $\mathrm{Sn} 3 \mathrm{Ag} 0.5 \mathrm{Cu} 0.06 \mathrm{Ni} 0.01 \mathrm{Ge}$ solder BGA packages with $\mathrm{Au} / \mathrm{Ni} / \mathrm{Cu}$ pads possess very similar ball shear strengths at 9.8 and 9.9 $\mathrm{N}$, respectively. After aging at 100 and $150^{\circ} \mathrm{C}$, the bonding strengths of the $\operatorname{Sn} 3 \mathrm{Ag} 0.5 \mathrm{Cu}$ and Sn3Ag0.5Cu0.06Ni0.01Ge solder joints have decreased to about $6.3 \pm 0.5$ and $8.0 \pm 0.4 \mathrm{~N}$, respectively. It is evidenced that the bonding strength of the $\mathrm{Sn} 3 \mathrm{Ag} 0.5 \mathrm{Cu} 0.06 \mathrm{Ni} 0.01 \mathrm{Ge}$ solder joints has degraded by about $19 \%$ due to the aging treatment, which is less than the amount of degradation for $\mathrm{Sn} 3 \mathrm{Ag} 0.5 \mathrm{Cu}(36 \%)$. Fractography of all specimens after ball shear tests reveals the ductility across the solder balls (Fig. 11); therefore, as compared to the case of $\mathrm{Sn} 3 \mathrm{Ag} 0.5 \mathrm{Cu} 0.06 \mathrm{Ni0} .01 \mathrm{Ge}$, the much higher degradation rate of the bonding shear strengths for aged $\mathrm{Sn} 3 \mathrm{Ag} 0.5 \mathrm{Cu}$ solder joints should be attributed to the greater softening tendency of the solder matrix which has arisen from the stronger coarsening effect of those $\mathrm{Ag}_{3} \mathrm{Sn}$ precipitates and $\mathrm{AuSn}_{4}$ intermetallics in $\mathrm{Sn} 3 \mathrm{Ag} 0.5 \mathrm{Cu}$.

\section{CONCLUSIONS}

The element $\mathrm{Ni}$, in trace amounts, has been added to the ternary eutectic $\mathrm{Sn} 3 \mathrm{Ag} 0.5 \mathrm{Cu}$ solder alloy for the purpose of improving its mechanical strength and wettability. ${ }^{2}$ This present study showed that the addition of $\mathrm{Ni}$ could also render distinct effects on the intermetallic reactions in those $\mathrm{Sn}-\mathrm{Ag}-\mathrm{Cu}$ BGA packages with $\mathrm{Au} / \mathrm{Ni}$ surface finishes. Experimental results revealed that continuous $\left(\mathrm{Cu}_{0.55} \mathrm{Ni}_{0.40} \mathrm{Au}_{0.05}\right)_{6} \mathrm{Sn}_{5}$ and $\left(\mathrm{Cu}_{0.64} \mathrm{Ni}_{0.34} \mathrm{Au}_{0.02}\right)_{6} \mathrm{Sn}_{5}$ intermetallic layers (IM1a and IM1b) were formed at the solder/pad interfaces of the reflowed $\mathrm{Sn} 3 \mathrm{Ag} 0.5 \mathrm{Cu}$ and Sn3Ag0.5Cu0.06Ni0.01Ge solder joints, respectively. In addition, $\mathrm{Ag}_{3} \mathrm{Sn}$ precipitates and $\mathrm{AuSn}_{4}$ intermetallics appeared in the as-reflowed solder matrices of both packages. Aging at 100 and $150^{\circ} \mathrm{C}$ caused the $\mathrm{Ag}_{3} \mathrm{Sn}$ and $\mathrm{AuSn}_{4}$ in the $\mathrm{Sn} 3 \mathrm{Ag} 0.5 \mathrm{Cu}$ solder joints to grow rapidly. The $\mathrm{AuSn}_{4}$ intermetallics even became gigantic in the $\mathrm{Sn} 3 \mathrm{Ag} 0.5 \mathrm{Cu}$ solder BGA packages. On the other hand, the coarsening of 

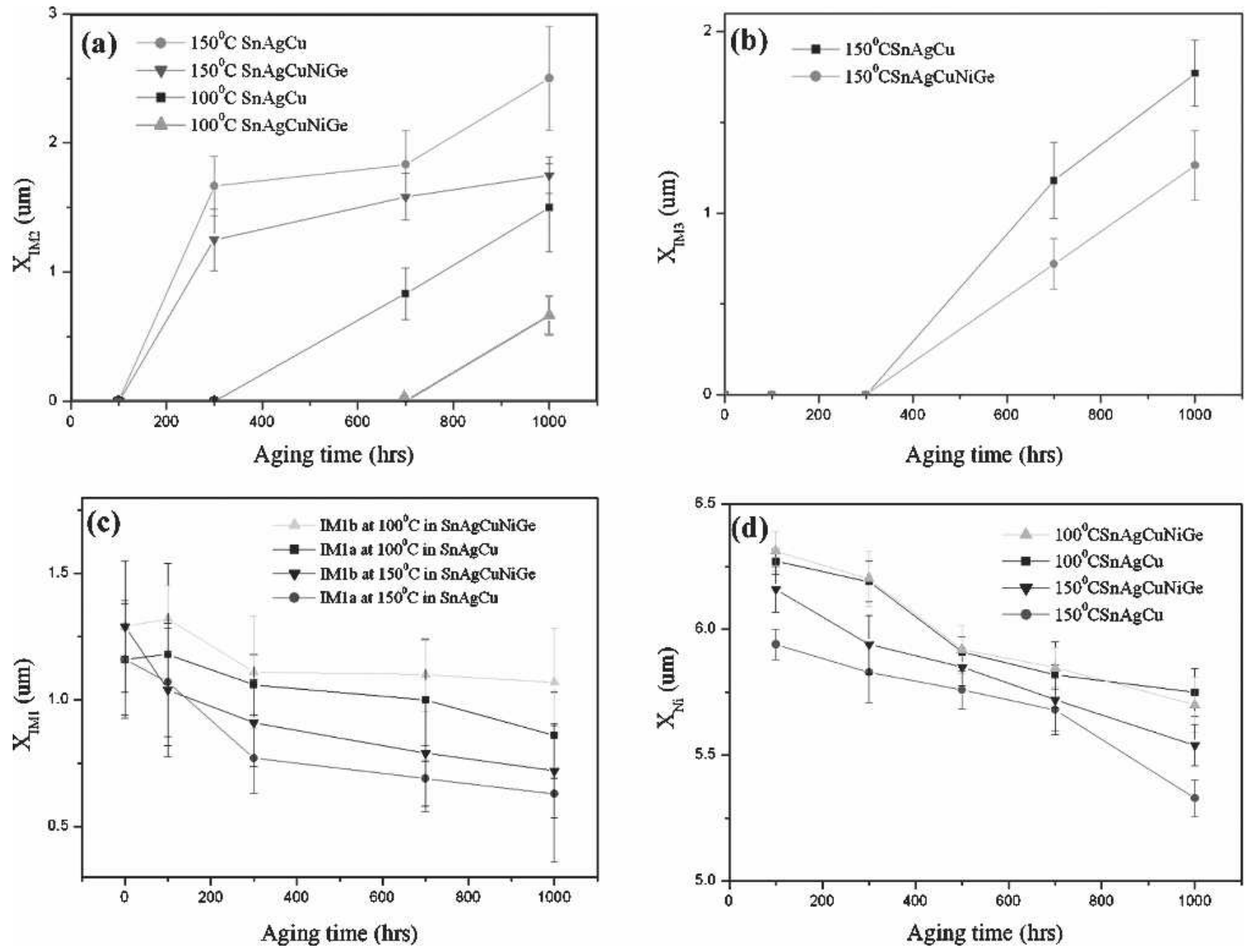

Fig. 9. The growth thicknesses $(X)$ of interfacial (a) IM2 (b) IM3 (c) IM1a and IM1b intermetallic layer and (d) the residual thickness $\left(X_{N i}\right)$ of $N i$ surface finishes in $\mathrm{Sn} 3 \mathrm{Ag} 0.5 \mathrm{Cu}$ and $\mathrm{Sn} 3 \mathrm{Ag} 0.5 \mathrm{Cu} 0.06 \mathrm{Ni0} .01 \mathrm{Ge}$ solder BGA packages after aging at $100^{\circ} \mathrm{C}$ and $150^{\circ} \mathrm{C}$ versus the aging time (t).

Table I. Ball Shear Strengths (N) of Sn3Ag0.5Cu and Sn3Ag0.5Cu0.06Ni0.01Ge BGA Packages with $\mathrm{Au} / \mathrm{Ni} / \mathrm{Cu}$ Pads After Aging at 100 and $150^{\circ} \mathrm{C}$ for Various Time Periods

\begin{tabular}{|c|c|c|c|c|}
\hline \multirow{2}{*}{$\begin{array}{l}\text { Aging } \\
\text { Time (hr) }\end{array}$} & \multicolumn{2}{|c|}{ Sn3Ag0.5Cu } & \multicolumn{2}{|c|}{ Sn3Ag0.5Cu0.06Ni0.01Ge } \\
\hline & 100 & 150 & 100 & 150 \\
\hline As reflowed & 9.8 & 9.8 & 9.9 & 9.9 \\
\hline 100 & 7.0 & 6.6 & 8.4 & 7.8 \\
\hline 300 & 6.9 & 6.3 & 8.1 & 8.0 \\
\hline 500 & 6.5 & 6.2 & 8.1 & 7.8 \\
\hline 700 & 6.4 & 6.1 & 7.9 & 7.6 \\
\hline 1000 & 6.0 & 6.0 & 7.5 & 7.3 \\
\hline
\end{tabular}

$\mathrm{Ag}_{3} \mathrm{Sn}$ precipitates was much slower, and the formation of gigantic $\mathrm{AuSn}_{4}$ intermetallics was inhibited in the aged Sn3Ag0.5Cu0.06Ni0.01Ge specimens. During the aging process, an extra $\left(\mathrm{Cu}_{0.50} \mathrm{Ni}_{0.42} \mathrm{Au}_{0.08}\right)_{6} \mathrm{Sn}_{5}$ intermetallic layer (IM2) with higher Au content appeared at the IM1a/Ni and IM1b/Ni interfaces. After

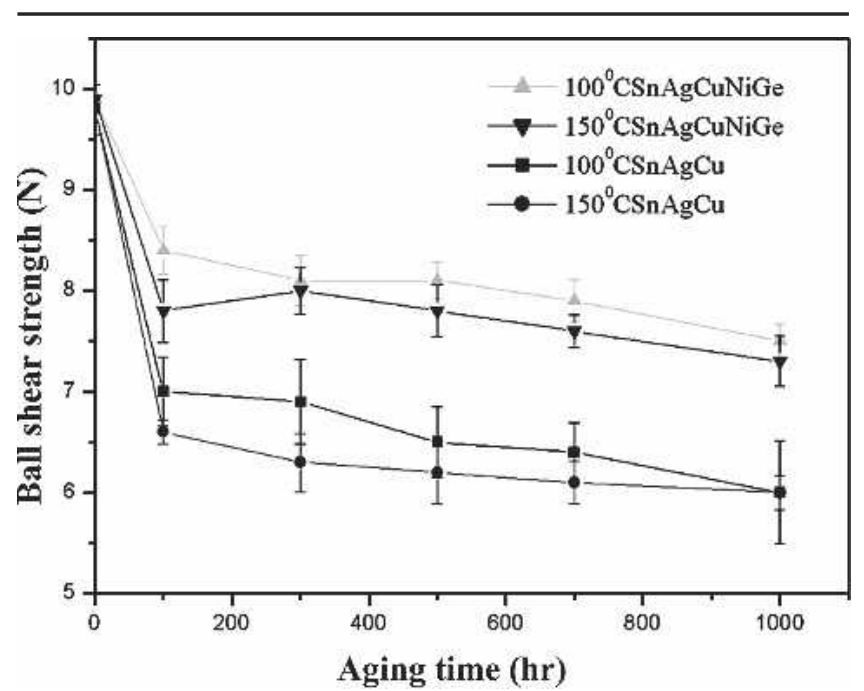

Fig. 10. Ball shear strengths of $\mathrm{Sn} 3 \mathrm{Ag} 0.5 \mathrm{Cu}$ and Sn3Ag0.5Cu0.06Ni0.01Ge solder BGA packages with $\mathrm{Au} / \mathrm{Ni} / \mathrm{Cu}$ pads after aging at $100^{\circ} \mathrm{C}$ and $150^{\circ} \mathrm{C}$ for various time periods. 

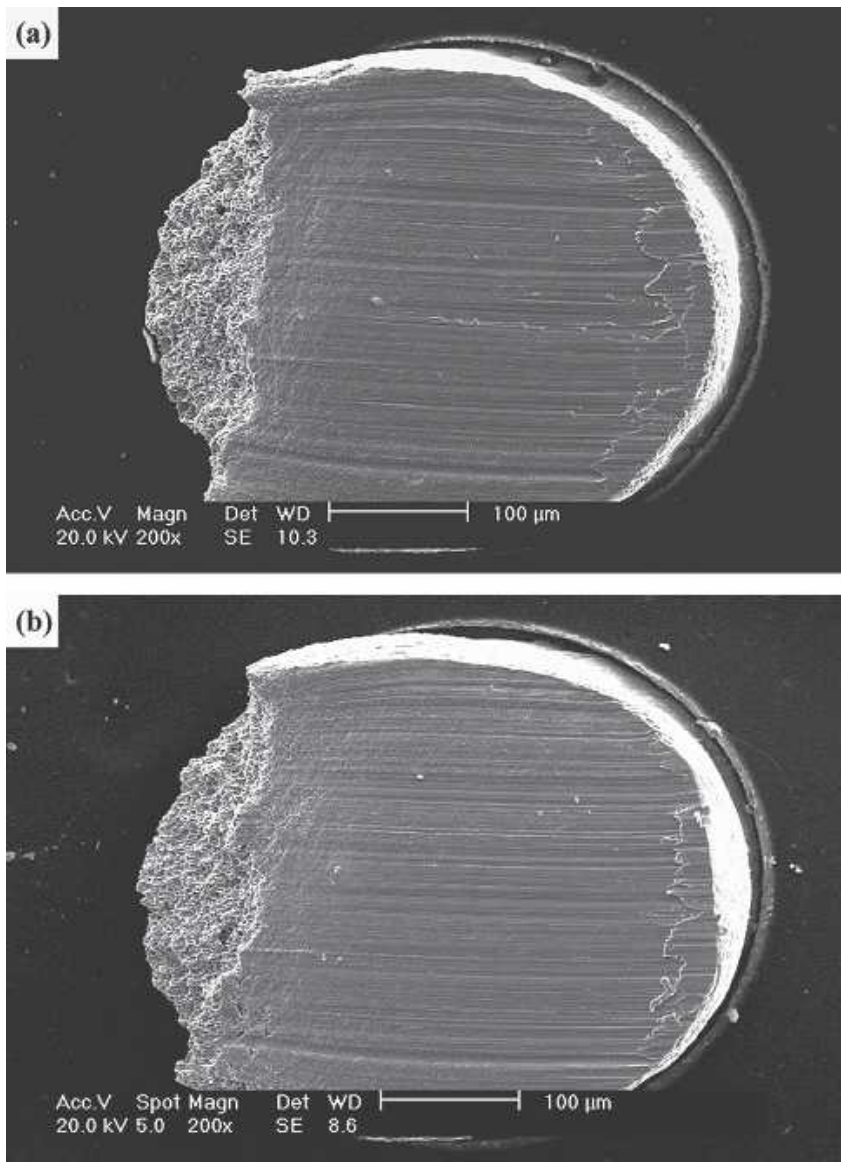

Fig. 11. Typical Fractography of the (a) Sn3Ag0.5Cu and (b) Sn3Ag0.5Cu0.06Ni0.01Ge solder joints in BGA packages after ball shear tests. prolonged aging, the continuous IM1a intermetallic layer diminished and became scallop shaped, allowing for the appearance of a $\left(\mathrm{Ni}_{0.87} \mathrm{Cu}_{0.12} \mathrm{Au}_{0.01}\right)_{3} \mathrm{Sn}_{4}$ intermetallic layer (IM3) at the IM2/Ni interface. The results also indicated that the growth thicknesses of both interfacial IM2 and IM3 intermetallic layers in $\mathrm{Sn} 3 \mathrm{Ag} 0.5 \mathrm{Cu} 0.06 \mathrm{Ni} 0.01 \mathrm{Ge}$ packages were lower than those for $\mathrm{Sn} 3 \mathrm{Ag} 0.5 \mathrm{Cu}$ packages. Aging treatments resulted in the softening of the solder matrix, which in turn led to the degradation of ball shear strengths in the $\mathrm{Sn} 3 \mathrm{Ag} 0.5 \mathrm{Cu}$ and Sn3Ag0.5Cu0.06Ni0.01Ge packages from 9.8 and $9.9 \mathrm{~N}$ (reflowed state) to about 6.3 and 8.0 (aged state), respectively.

\section{ACKNOWLEDGEMENT}

The authors sincerely thank the National Science Council, Taiwan, for sponsoring this research (grant NSC-93-2216-E002-024).

\section{REFERENCES}

1. K. Zeng and K.N. Tu, Mater. Sci. Eng. R 38, 55 (2002).

2. M. Yamashita, S. Tada, K. Shiokawa, and Fuzi Electric Co., "Solder Alloys," U.S. patent 6,179,935 B1 (2001).

3. K. Habu, N. Takeda, H. Watanabe, H. Ooki, J. Abe, T. Saito, Y. Taniguchi, and K. Takayama, Proc. Int. Conf. Electron. Environment, (New York: IEEE, 1999), p. 21.

4. C.M. Chuang and K.L. Lin, J. Electron. Mater. 33, 1426 (2003).

5. C.M. Chuang, P.C. Shi, and K.L. Lin, 2002 Int. Symp. Electron. Mater. Packag., IEEE, 360 (2002).

6. C.M. Chuang, P.C. Shi, and K.L. Lin, Proc. Int. Conf. Electron. Mater. Packag., (New York: IEEE, 2002), p. 360.

7. S.F. Yen, H.M. Wu, and T.H. Chuang, J. Electron. Mater. 35, 310 (2005).

8. T.H. Chuang, S.Y. Chang, L.C. Tsao, W.P. Weng, and H.M. Wu, J. Electron. Mater. 32, 195 (2003). 